\title{
DEATH OF LOCUS STANDI AND THE REBIRTH OF PUBLIC INTEREST LITIGATION IN THE ENFORCEMENT OF HUMAN RIGHTS IN NIGERIA: FUNDAMENTAL RIGHTS (ENFORCEMENT PROCEDURE) RULES 2009 IN FOCUS
}

\author{
R. K. Salman* \\ F. J. Oniekoro**
}

\begin{abstract}
One of the various mechanisms put in place in order to address human rights abuses in Nigeria is the Fundamental Rights (Enforcement Procedure) Rules 1979. However, the Rules were punctuated with different challenges and defects ranging from the problems of locus standi to unacceptability of public interest litigation. In an attempt to address this problem, the Fundamental Rights (Enforcement Procedure) Rules 2009 was enacted. This article engages in a critical assessment of the 2009 Rules with a view to ascertaining the extent to which the Rules have come to cure the 1979 Rules. The article begins with a critical examination of defects inherent in the 1979 Rules. It goes further to x-ray the developments brought by the 2009 Rules. The article posits that the 2009 Rules have come as a leverage to problems which have, in the past, denied many litigants the opportunity to enforce their rights and claim compensation. It concludes that if properly implemented, the 2009 Rules will phase out the identified defects and strengthen public interest litigation in the areas of human rights enforcement.
\end{abstract}

Keywords: locus standi, fundamental rights, enforcement, public interest litigation

LL. B (BUK); BL; LL. M (Ife); and Ph.D. (Malaysia) He is currently an Associate Professor and Head, Department of Professional Ethics and Skills at the Nigerian Law School, Lagos, Nigeria. E-mail:- rrsalman@yahoo.com \& salman@lawschoollagos. org Tel-: +2348066098771

** LL. B (LASU); BL; LL. M (NAU); He is currently an Associate Professor and Head, Department of Property Law at the Nigerian Law School, Enugu, Nigeria. E-mail-: frankiruosa@yahoo.com \& frankiruosa@gmail.com Tel-: +2347031946963 


\title{
KEMATIAN LOCUS STANDI DAN KELAHIRAN SEMULA TINDAKAN UNDANG-UNDANG KEPENTINGAN AWAM DALAM PENGUATKUASAAN HAK ASASI KEMANUSIAAN DI NIGERIA: KAEDAH-KAEDAH HAK-HAK ASAS (PROSEDUR PENGUATKUASAAN) 2009 DALAM FOKUS
}

\begin{abstract}
ABSTRAK
Salah satu mekanisme yang diwujudkan dalam kepelbagaian mekanisme yang ada bagi menangani penyalahgunaan hak asasi kemanusiaan di Nigeria ialah Kaedah-kaedah Hak-hak Asas (Prosedur Penguatkuasaan) 1979. Namun, kaedah-kaedah ini telah diselangi beberapa cabaran dan kecacatan yang terdiri daipada masalah locus standi serta penolakan tindakan undang-undang kepentingan awam. Kaedah-kaedah Asas (Prosedur Penguatkuasaan) 2009 telah diluluskan sebagai satu percubaan untuk menangani masalah ini. Makalah ini membuat penilaian kritikal kaedah-kaedah 2009 ini dengan tujuan memastikan sejauh mana ianya dapat menyelesaikan masalah-masalah yang timbul daripada penguatkuasaan Kaedahkaedah 1979. Bermula dengan penilaian kritis dalam mengenalpasti kecacatan yang wujud dalam Kaedah-kaedah 1979, makalah ini kemudiannya memeriksa pembaharuan yang dibawa oleh Kaedahkaedah 2009. 1 Makalah ini menghujahkan bahawa kaedah-kaedah 2009 mempunyai pengaruh terhadap masalah yang telah menafikan hak ramai litigan untuk mengambil kesempatan menguatkuasa hak mereka dan menuntut pampas dan sebelum ini. Makalah ini diakhiri dengan saranan sekiranya dilaksanakan dengan betul, kaedah-kaedah 2009 ini akan mengenepikan kecacatan-kecacatan yang dikenalpasti dan menguatkan tindakan undang-undang kepentingan awam dalam penguatkuasaan bidang hak asasi kemanusiaan.
\end{abstract}

Kata kunci: locus standi, hak-hak asas, penguatkuasaan, tindakan undangundang kepentingan awam 


\section{INTRODUCTION}

Nigeria has experienced and operated as many as five different constitutions with human rights flavour. The first among them is the 1960 Independece Constitution which featured human rights provisions. The inclusion of human rights is partially to allay the fear of the minority ${ }^{1}$ whose human rights was threatened by the majority groups. The Commission $^{2}$ that was set up to look into the threatened rights of the minorities recommended far-reaching provisions for the fundamental rights of Nigerian citizens. ${ }^{3}$ Just as the American Constitution (Bill of Rights) guaranteed certain individual rights to American citizens, the 1960 Nigerian Constitution guaranteed certain rights. On attaining republic, Nigeria had the 1963 Republic Constitution which had similar human rights provisions. The 1966 military coup d'état brought an end to the 1963 Constitution and introduced military rule which ruled by decrees and edicts that lasted for about 13 years. A new Constitution came to being in 1979, sometimes called the 1979 Constitution. Barely four years later, the military struck again and ruled for another 16 years and by Decree, suspended some of the human rights provisions in the constitution. The Babangida military regime introduced the 1989 Constitution. It was not implemented. In 1999, the country went back to democracy which ushered in the 1999 Constitution with human rights provisions. The 1999 constitution goes further by providing a Bill of Rights.

Despite these provisions in those constitutions, human rights violations in the form of executive dominance of statecraft, administrative excesses by the executive branch, breach of law, political repression, and weakening of the legislature generally as well as legislative lawlessness in some States' Houses of Assembly reign supreme. The judiciary which is saddled with the enforcement of human rights is incapacitated by the executive and legislature. The military rule in-between was the worst of it all when it comes to the violation of human rights.

For these reasons the enforcement of human rights became more compelling but the extant provisions or rules made it difficult. In

See the Report of the Commission Appointed to Inquire into the Fears of the Minorities and Means of Allaying Them Cmd 505 HMSO. London, 1958

2 It is christened "Henry Willink Commission 1958" after its chairman, Sir Henry Willink

3 Agiri Babatunde, "The Concept and Practice of Individual Rights in Nigeria, 1950-1966: How Relevant is the American Constitutional Experience?" American Studies International, Vol. 29 No. 2 (1991):1. 
order to nip the problem in the bud, the then Chief Justice of Nigeria, Hon. Justice Kutigi, enacted the 2009 Fundamental Rights (Enforcement Procedure) Rules. The question then is to what extent has the rule come to address inadequacies inherent in the 1979 Enforcement of fundamental rights procedure? To answer this question, this article is divided into three parts. The first part discusses the concept of human rights in Nigeria. The second part x-rays the enforcement of human rights in Nigeria and its attendant problems before the new Rules while the last part examines innovations put in place by the rules with a view to making enforcement of human rights in Nigeria a reality.

\section{THE CONCEPT OF HUMAN RIGHTS IN NIGERIA}

\section{Human Rights: A Contextual Position}

The twentieth century is regarded as the era of human rights. It is the century when many conventions,${ }^{4}$ treaties ${ }^{5}$ and protocols ${ }^{6}$ in respect of human rights were entered into after the adoption of Universal Declaration of Human Rights (UDHR) in 1984. ${ }^{7}$ It is also the epoch era when discourse on human rights became more pronounced. Since then, the reputation of human rights has been so high within the national and international scene. ${ }^{8}$ The discourse has been pervasive in law,

$4 \quad$ See for example, The International Covenant on Civil and Political Rights (ICCPR), GA res. 2200A (XXI), 21 UNGAOR Supp. (No. 16) at 52, UN Doc. A/6316 (1966), 999 UNTS 171, (entered into force March 23 1976); International Covenant on Economic Social and Cultural Rights (ICESCR) GA res. 2200A (XXI), 21 UNGAOR Supp. (No. 16) at 49, UN Doc. A/6316 (1966), 993 UNTS 3, (entered into force Jan. 3 1976); and Convention on the Rights of the Child, adopted 20 Nov. 1989, G.A. Res. 44/25, U.N. GAOR, 44th Sess., Supp. No. 49, U.N. Doc. A/44/49 (1989).

5 See for example, the African Charter on Human and Peoples' Rights (ACHPR) adopted June 27, 1981, OAU Doc. (It entered into force Oct. 21 1982).

6 See for example, Optional Protocol to the International Covenant on Civil and Political Rights; Optional Protocol of the Covenant on Economic, Social and Cultural Rights; and Optional Protocol to the Convention on the Elimination of Discrimination Against Women.

7 Universal Declaration of Human Rights, adopted 10 Dec. 1948, G.A. Res. 217A (III), U.N. GAOR, 3d Sess, U.N. Doc. A/RES/3/217A (1948) [hereinafter UDHR].

8 This is confirmed by the insightful academic opinions and discourse witnessed in the last fifty years. See for example Bobbio, Norberto, The Age of Rights (Cambridge: Polity, 1996) and Epp, Charles R., The Rights Revolution: Lawyers, Activist, and Supreme Courts in Comparative Perspective (Chicago: University of Chicago Press, 1998). 
politics, religion, ${ }^{9}$ internet, ${ }^{10}$ corporations, ${ }^{11}$ environment, and even in gender issues. ${ }^{12}$ It is so pervasive that there is rarely any position, claim, criticism or aspiration relating to social and political life that is not expressed in the language of rights. ${ }^{13}$ Their recognition, protection, promotion and enforcement have attracted the attention of individuals, groups, corporate entities, states and inter-governmental organisations. In fact, one of the striking developments in international law since the end of the Second World War has been a concern with the protection of human rights. ${ }^{14}$

There remain some fundamental and normative questions like what are human rights and why the pervasive popularity in recent years. The answer to the latter question is simple. It is due to serious attention people have paid to recent world events and the quest for international peace and order. The former question seems to be contentious but a satisfactory answer is needed in order to lay a strong foundation and legitimate claim for the potential holders of such rights and to provide sources of obligation for those who are expected to protect, promote and enforce the rights. In the past, many attempts have been made to define 'human rights'. ${ }^{15}$ Broadly, 'human rights' could be defined as rights human beings have by virtue of the fact that they are human

Dominic McGoldrick, Human Rights and Religion: The Islamic Headscarf Debate in Europe, (USA: Hart Publishing, 2006); Sifa Mtango, "A State of Oppression? Women's Rights in Saudi Arabia", Asia-Pacific Journal on Human Rights and the Law 1 (2004): 49-67.

10 Godwin,Mike, Cyber Rights: Defending Free Speech in the Digital Age, (London: MIT Press, 2003).

11 De Schutter Olivier, eds., Transnational Corporations and Human Rights, (Oregon: Hart Publishing, 2006).

12 Emerton Robyn, "Finding a Voice, Fighting for Rights: The Emergence of the Transgender Movement in Hong Kong." Inter-Asia Cultural Studies Vol. 7 No. 2, (2006):243-269.

13 Peter A. Atudiwe, Judicial Review and Enforcement of Human Rights: The Red Pencil and Blue Light of the Judiciary of Ghana (Canada: Queen's University, 2008), 33.

14 Robertson Arthur Henry, and John Graham Merrills, Human Rights in the World (Manchester: Manchester University Press, 1989), 10.

15 Fuller Lon Luvois , The Morality of Law (New Haven: Yale University Press, 1969); Hart, Herbert Lionel Adolphus, The Concept of Law (Oxford: Oxford University Press, 1961); Hart, Herbert Lionel Adolphus, "The Separation of Law and Moral" Harvard Law Review, Vol. 17 (1957-58): 592; Dworkin Ronald, Taking Rights Seriously (London: Duckworth, 1977); Joseph, Raz, The Morality of Freedom (Oxford: Oxford University Press, 1988); and Finnis J., Natural Law and Natural Rights (Oxford: Oxford University Press, 1980). 
being. ${ }^{16}$ In this sense human rights are conceived as naturally inherent in the human person. They are neither granted by the state nor are they the result of one's action. ${ }^{17}$ Thus, they are rights which all persons, everywhere and at all times, equally have by virtue of being moral and natural creatures. ${ }^{18}$

In a narrow context, human rights are claims or entitlements which people can demand from their state. They are claims or entitlements due to people, which the court shall enforce when they are asserted by the individual. ${ }^{19}$ In this sense, the states are expected to protect, promote and enforce them because the legitimate Grundnorm (the Constitution) or other legal instruments have provided for their enforcement. ${ }^{20}$ The legal protection and enforcement of human rights, to a larger extent, depends on the enactment of specific rules laying down the rights of citizens and duties of the government to respect them. ${ }^{21}$ Where such rules clearly identify who has the rights, who has the correlative duties and establish remedies for violation, procedures for enforcement are imperative. ${ }^{22}$

\section{Evolution of Human Rights in Nigeria}

The development of human rights in Nigeria passed through three regimes. The first regime of human rights in Nigeria took place from inception of the African society till around 1800 when the colonial masters first set their foot on the African soil. Before 1914, there was

16 Peter A. Atudiwe, Judicial Review and Enforcement, 34. See also Jack Donnelly, Universal Human Rights: In Theory and Practice (Cornell: Cornell University Press, 2003); Brian Orend, Human Rights: Concept and Context, (Peterborough: Broadview Press, 2002); Cranston Maurice, What Are Human Rights (New York: Taplinger Publishing, 1973); and Michael Freeman, "The Philosophical Foundations of Human Rights" Human Rights Quarterly, Vol. 16, (1994) :491.

17 Jack Donnelly, "Human Rights and Dignity: An Analytic Critique of Non-Western Conceptions of Human Rights" in Human Rights Law,ed. Philip Alston (Aldershot England: Dartmouth Publishing Cop. Ltd, 1996), 305.

18 Osita Nnamani Ogbu, Human Rights Law and Practice in Nigeria: An Introduction (Enugu: CIDJAP Press, 1999): 2.

19 Steve Foster, Human Rights and Civil Liberties, (Great Britain: Pearson Education Ltd, 2008) at 4

20 Peter A. Atudiwe, Judicial Review and Enforcement, 34: See also Freeman S., Human Rights (Cambridge: Polity, 2000); Steiner, Hillel, An Essay on Rights (Oxford: Blackwell, 1994).

${ }_{21}$ Tom Campbell, Rights: A Critical Introduction (New York: Routledge, 2006), 89.

22 Ibid. 
no entity called Nigeria, but there existed units or independent "states or ethnic groups" with autonomy restricted only by conquest or fear of larger units of people. ${ }^{23}$ These groups of people sometimes referred to as small-scale states, each had a different code of conduct independent of others. Thus, the plurality of these ethnic groups that now populated Nigeria, (with their attendant plural customs, languages and social practice) may account for the complex views of what constitute the rights of individuals within the society. An exploration of human rights practices in traditional societies is therefore an exploration of several different societies on their evolutionary path of being unified into nationhood. ${ }^{24}$

Britain colonised Nigeria and its administration in various parts of Nigeria was determined by the mode of conquest of such areas. Territories came under British jurisdiction in three ways -by cession, by conquest and by treaty arrangements. ${ }^{25}$ There was an accepted legal distinction in the effect of these different modes of acquisition. Acquisition by cession or conquest rendered the conquered or ceded territories of the British Isles, thereby making the laws of England operational. ${ }^{26}$ Hence, those who fell under this arrangement were

${ }^{23}$ Victor S. Dugga, "Human Rights in Traditional Societies: A Lesson for Nigeria in the Twenty-First Century" in Individual Rights and Communal Responsibility in Nigeria, eds. Muhammed Tabiu and Muhammed Tawfiq Ladan (Abuja: Nigeria NHRC, 1998): 11.

24 For critical analysis of culture and civilization and of course human rights practice of this regime see Samuel Johnson, The History of Yorubas: From the Earliest Time to the Beginning of the British Protectorate (Lagos: C. M. S (Nigeria) Bookshop, 1921), 40; Omoni Oluwole. "Formation of town associations among the Yoruba: A response to colonial situation." Odu: A Journal of West Africa Studies No.38 (1991): 129; Egbe Ifie, "Early Nigerian Civilisation" Culture and Civilisations, ed. Lloyd Thompson (Ibadan: Africa-Link Books, 1991), 153; Kasim Kigbu, "The Eggon People: An Early History" in The Eggon of Southern Nigeria ed.D. Anzaku et al (Jos: Andex Press, 1966),33; An-naim, Abdullahi, and Francis M. Den “Introduction” in Human Rights in Africa: Cross Cultural Perspectives, eds. Abdullahi An-naim, and Francis M. Den, (Washington DC: Brookings Institute, 1990), v; and the classical work of Chinua Achebe, Things Fall Apart (Port Harcourt: Heinemann Education Publisher, 1958).

25 While Lagos, the major centre of commercial activity in South Nigeria, was acquired by cession, the Northern territories of the Sokoto caliphate were won by conquest. The rest of the country was acquired by so-called 'bilateral treaties of friendship and trade' where local people agreed to come under British jurisdiction. See Bonny Ibhawoh, "Stronger than the Maxim Gun Law, Human Rights and British Colonial Hegemony in Nigeria" African Studies, Vol. 72, (2002): 59.

26 Ordinance No. 3 of 1863; The Supreme Court Ordinance of 1876 which established a Supreme Court for the colony also spelt out that English common law and the doctrines of general application in England as at 1874 would be in force. 
regarded, in principle, British subjects thereby entitled to the legal rights and liberties of the Englishman and owing their allegiance to the Crown. Other occupants on the territories under treaty enjoyed other status with different ordinances. Thus, as at 1900, Nigeria was an amalgam of a colony and two protectorates in which the British Crown had complete control and sovereignty. ${ }^{27}$ The entitlement of rights and liberties by the British subjects in Nigeria indicated that the concept of human rights existed during this period. However, the extent to which the subjects enjoyed them was a matter of concern. This period witnessed the second regime of human rights which coincided with formal recognition and acceptance of the Universal Declaration of Human Rights by the United Nations to safeguard freedom, justice and peace in the world. ${ }^{28}$

The emergence of democracy in 1960, 1979 and later in 1999 marks the beginning of the third human rights regime in Nigeria with its attendant 1960, 1963, 1979 and 1999 Constitutions. Unlike in the past, the framers of these constitutions were much aware of the significance of human rights protection and enforcement. Their experiences in the past and the fact that Nigeria is a signatory to many international human rights treaties and conventions were major guides when the Nigerian Bill of Rights was being drafted. ${ }^{29}$ Inevitably, this background influenced their deliberations on the nature and future of human rights in Nigeria. Their deliberation culminated into elaborate but entrenched provisions on human rights. The 1979 and 1999 Constitutions go further to provide for civil and political rights like rights to life; ${ }^{30}$ dignity; ${ }^{31}$ personal liberty $; 2$ fair hearing; ${ }^{33}$ freedom of thought, conscience and religion; ${ }^{34}$

27 Karibi-Wyhte, A. G., The Relevance of the Judiciary in the Polity: A Historical Perspective (Lagos: Nigerian Institute of Advance Legal Studies, 1987), 12.

28 United Nations, "Universal Declaration of Human Rights" in On Human Rights, ed. Paul Mallia (Kenya: St. Paul Publication, n. d), 46.

29 Nigeria Report, National Action Plan for the Promotion and Protection of Human Rights in Nigeria (Abuja: Federal Republic Nigeria, 2006), 10.

30 See section 33 (1) 1999 Constitution and Okoro $v$ The State [1988] 5 NWLR (pt. 94) 255.

31 See section 34 (1) of the 1999 Constitution and Uzoukwu v Ezeonu II [1991] 6 NWLR (pt. 200) 708.

32 See section 35 (1) 1999 Constitution and Adewale v Jakande (1982) NCLR 262.

33 See Section 36 (1) (2), 1999 Constitution; Ransome Kuti v A. G. Federation [1985] 2 NWLR (pt. 6) 211; and Veritas Company Ltd v City Trust Investment [1993] 3 NWLR (pt. 281) 349 .

$34 \quad$ See section 38 (1) 1999 Constitution and Theresa Onwo v Oko [1996] 6 NWLR (pt. 456) 612. 
freedom of expression and the press; ${ }^{35}$ peaceful assembly and association, ${ }^{36}$ and freedom of movement. ${ }^{37}$

Fundamental Objectives and Directive Principles of State Policy in Chapter $\mathrm{II}^{38}$ also recognised Economic, Social and Cultural Rights -although non-justiciable. ${ }^{39}$ The entrenchment of human rights provisions in the Constitution was aimed at creating a society that protects political freedom as well as the social and economic well-being of Nigerians. ${ }^{40}$ Strengthening democratic institutions of government to counter the dominance of executive powers was then essential for the rule of law. ${ }^{41}$ The Constitutions met international and regional human rights requirements. In fact, for some historical reasons they went even further than these instruments. ${ }^{42}$ Despite this, however, human rights violations remain unabate ${ }^{43}$ and necessary mechanism ${ }^{44}$ put in place were inadequate to protect, promote and enforce them; one of such mechanisms was the Fundamental Rights (Enforcement Procedure) Rules of 1979.

\section{ENFORCEMENT OF HUMAN RIGHTS UNDER THE 1979 RULES}

Before the 1979 Constitution there was no rule for the enforcement of

35 See section 39 (1) \& (2) 1999 Constitution; Tony Momoh v Senate (1984) 4 NCLR 269; and Adikwe v Federal House of Representatives (1982) 3 NCLR 394.

36 See section 40 of the 1999 Constitution; Anigboror $v$ Sea Trucks (Nig) Ltd [1995] 6 NWLR (pt. 399) 35 ; Aniekwe v Okereke [1996] 6 NWLR (pt. 452) 60; and Rimi v People's Redemption Party Suit N. M/133/80 of 23/ 12/ 90.

37 See section 411999 Constitution; Minister of Internal Affairs v Shugaba (1982) 3 NCLR 915; and A. G. Federation v Ajayi [2000] 12 NWLR (pt. 682) 509.

38 See Chapter II of the 1979 and 1999 Constitutions respectively.

39 The non-justiciability of the socio-economic rights has received criticism from many writers. For example, see Abiola Ojo, "The Objective and Directive of the State Policy Must be Expunged" in Great Debate-Nigerian Viewpoints on the Draft Constitution (Lagos: Daily Times, 1977), 47.

$40 \quad$ See Chapter 2 and 4 of the Nigerian 1999 Constitutions.

${ }_{41}$ Lutisone Salevao, Rule of Law, Legitimate Governance and Development in the Pacific (Asia Pacific Press, 2005), 42.

42 See sections 13-24 and 33- 44 of 1999 Constitution.

43 See for example, Philip C. Aka, "Nigeria Since May 1999: Understanding the Paradox of Civil Rule and Human Rights Violations Under President Olusegun Obasanjo" San Diego International Law Journal Vol. 4, (2003): 266.

44 There are courts established under sections 230 - 296 of the 1999 Constitutions; Nigerian National Human Rights Commission was established in 1995 for the enforcement, protection and promotion of human rights. 
human rights as enshrined in the 1960 and 1963 Constitutions. ${ }^{45}$ That does not mean that human rights were not violated neither does it mean that such violation were not subject of litigation in courts. Under the 1960 and 1963 Constitutions, human rights were enforced in court through the prerogative orders of mandamus, ${ }^{46}$ prohibition, ${ }^{47}$ certiorari,${ }^{48}$ habeas corpus $^{49}$ and some other declaratory reliefs. ${ }^{50}$ With the inception of the 1979 Constitution the Fundamental Rights (Enforcement Procedure) Rules $1979^{51}$ was passed pursuant to the 1979 Constitution. The rules state when, where and how an applicant can enforce his right which has been, is being or is likely to be infringed. ${ }^{52}$ As expected there was a floodgate of cases involving enforcement of human rights violations in Court. ${ }^{53}$ However, many of these cases were dismissed on various reasons ranging from lack of jurisdiction to lack of locus standi and other technical grounds.

\section{Problems Associated with the 1979 Rules}

Ordinarily, the rules regulating the modus operandi for enforcement of human rights in Nigeria ought to be a source of joy to both applicants and practitioners. However, the reverse was the case because their hopes were dashed when their cases were dismissed or struck out for various reasons. In dismissing many cases involving enforcement of human rights under the 1979 Rules, the courts have hidden under different disguises.

\section{Mode of enforcement of human rights}

It has long been held in a plethora of cases that any aggrieved party

\footnotetext{
45 Fidelis Nwadialo, Civil Procedure in Nigeria (Lagos: University of Lagos Press, 2000), 1091.

46 See Shitta-Bey v Federal Public Service Commission (1981) 1 SC 40.

$47 \quad$ See Okapu v Resident, Plateau Province (1958) NRNLR 5.

48 See Arizika v Governor, Northern Region (1961) All NLR 379.

49 See Commissioner of Police v Agbaje (1969) 1 NMLR 176.

50 For this see Olawoyin v A. G. Northern Region (1961) 1 All NLR 269; Aoko v Fagbemi (1961) 1 All NLR 400; Fajimi v Speaker, Western House of Assembly (1962) 1 All NLR (pt. 1) 205; and Akande v Araoye (1968) NMLR 283.

51 It was enacted by Hon. Justice Atanda Fatai Williams (the then Chief Justice of Nigeria) in the exercise of the powers conferred on him by section 42(3) of the 1979 Constitution. The Rules are herein subsequently referred to and interchangeably used as 'old rules' or '1979 Rules.'

52 Or. 1 R. 2(1).

53 Court was interpreted to mean both Federal and State High Court. See Or. 1 R.1(2).
} 
is at liberty to approach the court for redress in any manner which indicates a violation of a right particularly where no particular mode of procedure has been prescribed. ${ }^{54}$ This position was reinstated by the Supreme Court when it said-:

..it seems to me that the whole complaint of the appellant in this respect is an attempt to draw a red herring. Let us ask the question: has the court, that is, the High Court Jurisdiction to take an originating summons on issues affecting Fundamental Rights? Of course the answer is in the affirmative. The Constitution itself (that is 1979 Constitution) spells out in its Chapter IV the Fundamental Rights of the citizen. So be it, but it did not stop there. Section 42 of the 1979 Constitution gives the High Court a special jurisdiction in respect thereof... It is my view that it would not matter by what manner that application has been made, once it is clear that it seeks redress for infringement of the rights so guaranteed under the constitution. ${ }^{55}$

Against this backdrop, many applicants seemingly assumed that any of the available procedures can be used to enforce their rights when such were breached. However, this position did not last long as many cases were later dismissed on the ground that the laid down procedure and mode of commencing human rights enforcement was not followed. ${ }^{56}$ The problem was so acute to the extent that the Supreme Court gave several contradictory decisions on whether or not any other procedure apart from the laid down procedure in the 1979 Rules can be adopted in the enforcement of human rights..$^{57}$ Indeed, as a result of the confusion created by the court, many applicants lost the opportunity to enforce their rights on the basis of wrong mode of commencement

\section{Derogations and restrictions in the interest of public defence}

One of the major problems associated with enforcement of human rights in Nigeria was the principle of derogation from enforceable rights. Notwithstanding that the Constitution provides for certain rights as fundamental and inalienable, yet such rights are denied and restricted as non-existent on the basis that their enforcement is against public policy, interest, order, morality or health. ${ }^{58}$ Such rights under

\footnotetext{
$54 \quad$ See for example Taiwo Aoko V Fagbemi \& DPP (1961) 1 ALL NLR 416.

$55 \quad$ Per Eso JSC in Saude v Abdullahi (1989) 4 NWLR (pt. 116) 387 at 418.

$56 \quad$ See for example Din v A. G. of the Federation (1988) 4 NWLR (pt. 87) 147.

$57 \quad$ See Boniface Ezechukwu v Peter Maduka (1997) 8 NWLR (pt. 518) 635 and

Dangote v Civil Service Commission of Plateau State (2001) 4 NWLR (pt. 717) 132 Compare with Ogugu v The State (1996) 9 NWLR (pt. 492) 1.

58 Femi Falana, Fundamental Rights Enforcement in Nigeria (Lagos: Legal Text
} 
derogation include freedom of association with its attached rights to go on strike. In Ogungbesan v Minister of Health and Social Services, ${ }^{59}$ the applicants sued the respondents to enforce their rights to freedom of association. The court dismissed the suit on the ground that the applicants were engaged to provide essential services and as such their rights to embark on industrial action was properly derogated upon by the Act of National Assembly ${ }^{60}$ in the interest of public health.

\section{Enforcement against private individuals}

Essentially, the greatest violator of human rights in Nigeria is the state. The violation of human rights recorded during the military era in Nigeria is unprecedented. ${ }^{61}$ In fact, Nigeria became a pariah nation due to its gross violation of human rights during the military era, particularly between 1994 and $1998 .{ }^{62}$ Owing to this fact, it is generally believed that actions to infringement of such rights can only be brought against the government or any of its agencies or officials but not against private individuals. The Nigerian courts erroneously interpreted the Constitution as such and in many occasions held that fundamental rights can only be enforced against the state. ${ }^{63}$

The erroneous belief was reinforced by the Federal High Court in Aderinto v Omojola $^{64}$ and Aidamebor v Obamogie ${ }^{65}$ where the court adopted the Court of Appeal's provisions, in full force including its error. According to the court, "the provision of Chapter IV of the Constitution are designed to protect the fundamental rights of individual citizens of Nigeria against the tyranny and excesses of government and/

Publishing Company Ltd, 2004), 10.

59 (1995) FHCLR 168.

60 The court relied heavily on Trade Dispute (Essential Services) Act, now Cap. T9 LFN 2004.

61 Philip C. Aka, "Prospect for Igbo Human Rights in Nigeria in the New Century" Howard Law Journal 165, 48, (Fall 2004): 3.

${ }^{62}$ Rahman. K. Salman, "The Effectiveness of the Nigerian National Human Rights Commission in Human Rights Protection" (PhD diss., International Islamic University Malaysia, 2011), 8.

63 See Minister of Internal Affairs $v$ Shugaba Abdulrahaman Darman (1982) 3 NCLR 915.

64 (1998) 1 FHCLR 101. The Court, Per Auta, J. fell into error when it held that "the entrenchment of a right in the Constitution does not create rights where none existed before, rather it is merely intended to protect existing rights from subsequent legislative interference and to enable their assertion against arbitrary, oppressive and illegal executive actions. As put by Justice O. O. Coker.the provisions are designed to protect the citizens from the strong arm of the executive," 104.

65 (1989) FHCLR 505. 
or their agencies and not against other fellow individual citizens." As a result of this position, many applicants lost their suits on the account that their suit cannot be enforced against individual notwithstanding that such individuals manifestly infringed rights of those applicants. It took some time before the Court of Appeal ${ }^{66}$ and later the Supreme Court ${ }^{67}$ could finally lay to rest that both government, its agencies and individuals can be sued where such government, its agencies or individual violate the rights of others.

\section{Enforcement of rights outside the State of breach (Jurisdiction)}

Under the old rules, there was the ranging problem of where to commence the proceedings vis-a-vis where the breach arose. Thus, enforcement of human rights must commence only in the 'Court' of a state where the breach was committed. ${ }^{68}$ The Court is defined by the Constitution to mean State or Federal High Court ${ }^{69}$ but such Court must be in existence in the State where the breach occurred..$^{70}$ However, the problem became serious in a situation where no State or Federal High Court is established in a State where the breach occurred. The Supreme Court added to the problem while considering such situations like this in the case of Tukur $v$ Government of Gongola State..$^{71}$ Here, the Applicant/Appellant (an Emir who was deposed and banished in Gongola State) commenced proceedings against the Governor of Gongola State in Kano State -another State of Nigeria in order to enforce his fundamental right purportedly breached by the Gongola State Governor. After a series of appeals to the apex court, the court held that the Constitution did not provide for any application to be made to a High Court sitting outside the State where the infringement occurred. ${ }^{72}$ The problem persisted for long because many states were

\footnotetext{
66 See Uzoukwu v Ezeonu II (1991) 6 NWLR (pt. 200) 708 and Theresa Onwo v Nwafor (1996) 6 NWLR (pt. 456) 584.

$67 \quad$ See Garba v University of Maiduguri (1986) 4 NWLP (pt. 18) 559.

68 See Oyakhire v Umar (1998) 3 NWLR (pt. 542) 438; Fabunmi v Commissioner of Police, Osun State (2001) 2 FHCLR 380; and Military Administrator Benue State v Abayilo (2001) FWLR (pt. 45) 602.

69 See Order 1 Rule 2 Enforcement Procedure Rule, 1979.

70 See section 42 (1) 1979 Constitution and section 46 (1) 1999 Constitution (as amended).

$71 \quad$ (1989) 4 NWLR (pt. 117) 517.

72 The Supreme Court stated further "From the above facts, even before considering the claim or Relief sought which normally should determine jurisdiction, one initial question suggests itself - why go to Kano State to sue for a cause of action which arose in Gongola State? It is here that one may have to look rather closely at Section 42 (1) of the 1979 Constitution which invested the 'High Court' with Special Jurisdiction
} 
created without a division of the Federal High Court with jurisdiction to entertain issues related to enforcement of human rights.

\section{Locus standi of the applicant}

Another major obstacle faced during the regime of 1979 Rules was the problem of locus standi. The concept of locus standi or the law of standing is the set of rules which determine whether a person who initiates legal proceeding is a proper person to do so. Locus standi has its root in common law as developed in England. The doctrine of locus standi has been argued to have developed in the first place, under both English ${ }^{73}$ and Roman-Dutch law, to ensure that courts play their proper function of protecting the rule of law among others. ${ }^{74}$ The traditional model of adjudication, in its peculiar feature of being parties-driven, clearly identifies the plaintiff/ claimant as the initiator of legal proceedings. It further assumes that such plaintiff would have suffered injury or anticipates injury which ultimately precipitates the legal claim. In other words, such party is directly connected with certain injury and will benefit from the outcome of the litigation. That is, he must have locus standi to proceed with such claim.

On this premise and in line with the 1979 Rules, it is only a person whose fundamental right(s) has been, is being or is likely to be violated that can challenge such violation. In other words, to invoke the jurisdiction of a High Court for the protection of any of the fundamental rights guaranteed under Chapter IV of the Constitution, the applicant

\footnotetext{
' to deal with breaches of the fundamental rights provisions of Chapter IV of the Constitution...... in this case, Alhaji Umar Abba Tukur is complaining that there has been a breach of one or other of his fundamental right to his liberty or to his freedom of movement. The contravention alleged took place in Gongola State. From section 42 (1) above, he has to apply to a 'High Court' in that state, that is, the High Court where the contravention or breach occurred. The Federal High Court Kano cannot be a 'High Court in that state' which was envisaged by section 42 (1) above..... it is therefore my view that by choosing a Court outside the territorial boundaries of Gongola State where the fundamental rights were breached, the appellant in this case did not 'apply to a High Court in that State' as provided by Section 42 (1) of the 1979 Constitution." Per Oputa JSC at 530.

73 See Gouriet v Union of Post Office Workers \& Ors [1977] 3 All ER 70 (HL) (except where statute otherwise provided, a private person could only bring an action to restrain a threatened breach of law if his claim was based on an allegation that the threatened breach would constitute an infringement of his private rights or would inflict special damage to him.) This position is reiterated by the House of Lords in $X$ and Ors v Dorset County Council and other Appeals [1995] 3 All ER 353.

74 Tumai Murombo, "Strengthening Locus Standi in Public Environmental Litigation: Has Leadership Moved From the United States to South Africa?", Law, Environment and Development Journal Vol. 6 No. 2, (2010) : 167.
} 
must be the actual person whose right(s) has been breached. ${ }^{75}$ In fact on no condition or circumstance can an application be filed in the name of any other person other than that of the complainant. ${ }^{76}$ What was experienced over a period of thirty years was a total denial of access to justice by the affected complainants whose cases fell in this category. In most cases, the complainants were in military detention and as such it was practically impossible for them to institute actions by themselves. While suits were instituted by their relatives, such suits were dismissed on the basis that such relatives lacked locus standi.

\section{Time frame within which to commence enforcement proceedings}

Where an applicant passed through the various hurdles discussed above, another major litmus test which the applicant must pass has to do with the issue of limitation period. Ordinarily, it is trite law that where a law provides for bringing an action within a stipulated time, any action brought thereafter will be statute barred..$^{77}$ The application of this principle of law is further extended to the enforcement of human rights procedure in Nigeria. Thus, an applicant must ensure that his action is brought before the expiration of the stated period, otherwise, his action will be dismissed. The limitation period within which infringed rights should be enforced is 12 months. ${ }^{78}$ In interpreting this rule many judges have not only declined jurisdiction they have also dismissed many applications for the enforcement of human rights which were brought after the 12 months stipulated. ${ }^{79}$

The inelegant manner in which Order 1 Rule 3(1) was drafted as well as decisions that followed it has been criticised by the Court of Appeal when it said that "with respect to the draftsmen of the Rules, Order 1 Rule 3(1) is very badly framed." ${ }^{80}$ This portrayed that the application of this Rule had brought difficulties to both the courts and applicants in human rights enforcement proceedings.

\footnotetext{
75 See Oyegbemi v A. G. Federation (1982) 3 NCLR 895.

76 See Asemota v Colonel Yusuf (1981) 1 NCLR 420.

77 Femi Falana, Fundamental Rights Enforcement in Nigeria, 86.

78 Order 1 Rule 3(1) provides that "leave shall not be granted to apply for an order under these Rules unless the application is made within twelve months from the date of the happenings of the event, matter or act complained of, or such other period as may be prescribed by any enactment ....."

79 See Egbe v Adefarasin (1985) 1 NWLR (pt. 3) 549; Kayode Akanbi v Constable Dauda Gnagnatus (1984) 5 NCLR 722; Abia State University v Anyaibe (1996) 3 NWLR (pt. 439) 646; and Oguegbe v Inspector General of Police (1999) 1 FHCLR 59. 80 Per Katsina-Alu JCA (as he then was) in Tafida $v$ Abubakar (1992) 2 NWLR (pt. 230) 511 at 514.
} 
Inapplicability of public interest litigation in human rights enforcement Public Interest Litigation (PIL) has been defined as litigation in which 'a High Court allows volunteers like lawyers, activists, NGOs or citizen petitioners to bring a case on behalf of some victimised group without sufficient means or access to legal services. ${ }^{81}$ It has also been defined by an Australian court as 'the public character to which the litigation relates; evidenced by properly bringing proceedings to advance a public interest; that proceedings contribute to the proper understanding of the law in question; and having involved no private gain. ${ }^{82}$ The basic and crucial factor in PIL is the effect of the decision. That is, whether the action is instituted by an individual, organisation or a class action, and even if the remedy will benefit the applicant directly, the litigation will still benefit the public interest and have impact on the wider public. ${ }^{83}$

Specifically, public interest litigation stems from the standing rule developed by the UK courts and adopted by many jurisdictions. It involves individuals, corporations or a group purporting to represent the public interest, and not the interest of any identified or identifiable individuals. ${ }^{84}$ Public interest litigation has, among others, the following values; it provides effective judicial protection of weaker sections of the community; ensures access to justice; protects and sustains democratic governance and the rule of law; ${ }^{85}$ and makes officialdom accountable. ${ }^{86}$ The rule of standing (PIL) has been adopted in many jurisdictions with varying degrees in accordance with their socio-political situations. ${ }^{87}$

81 Modhurima Dasgupta, "Public Interest Litigation for Labour: How Indian Supreme Court Protects the Rights of India's most Disadvantaged Workers", Contemporary South Asia, Vol. 16 No. 2, (2008): 160.

82 Oshlack v Richmond River Council (1997) 152 ALR 83.

83 Gurdial Singh Nijar, "Public Interest Litigation: A Matter of Justice an Asian Perspective" 2, accessed March 25, 2013, http://asianlawassociation.org/aGAdocs/ malaysiapdf.

84 Jona Razzaque, Public Interest Environmental Litigation in India, Pakistan and Bangladesh (London: Kluwer Law International, 2004), 270.

85 Gurdial Singh Nijar, "Public Interest Litigation: A Matter," 3

86 Durbach Andrea. "Test Case Mediation-Privatising the Public Interest." Australian Dispute Resolution Journal 233 (1995): 238.

87 For varying degrees of practice and adoption of standing in various jurisdictions see Peter Cane, "Standing, Representation, and the Environment" in A Special Relationship? American Influences on Public Law in the UK, ed. Ian Loveland (Oxford: Clarendon Press, 1995); Chris Himsworth, "No Standing Still on Standing" in Administrative Law Facing the Future: Old Constraints and New Horizons, eds. Peter Leyland and Terry Woods (London: Blackstone, 1997); Carol Harlow, "Public Interest Litigation in England: The State of the Art" in Public Interest Law eds. Copper, J. and R. Dhavan (New York: Basil Blackwell, 1986); Richard Gordon QC, Judicial Review and Crown Office Practice (London: Sweet \& Maxwell, 1999); Jain, Mahabir 
However, as plausible as adoption of this principle is, the 1979 Rules did not take into consideration the application of public interest litigation in the enforcement of human rights where such rights do not affect an individual but the the public in general. The first case that tested the public interest litigation of a Plaintiff is the case of Olawoyin v. A. G Northern Region ${ }^{88}$ Here, the Applicant challenged the constitutionality of an Act ${ }^{89}$ which prohibited political activities by juveniles and prescribed penalties on juveniles and others who are parties to certain specified offences. The Applicant contended that he wished to give political education to his children but if the Act was enforced his rights and rights of other people of similar mind relating to freedom of conscience and freedom of expression will be infringed. The Federal Supreme Court held that it is only a person who is in imminent danger of coming into conflict with a law, or whose normal business or other activities have been directly interfered with by or under the law, that has sufficient interest to sustain a claim for the infringement of his rights.

Almost two decades later, the decision and reasoning in Olawoyin were re-affirmed and adopted in the case of Adesanya $v$ President of the Federal Republic of Nigeria. ${ }^{90}$ In this case, the appellant challenged the constitutionality of the appointment of a serving Judge as Chairman of the Federal Electoral Commission by the President of the Federal Republic of Nigeria. The Supreme Court by a majority ${ }^{91}$ was of the view that an individual plaintiff cannot institute public interest litigation except he is personally and directly affected by the act complained of or the infringed rights. In quick succession were the cases of $A$ G Akwa Ibom State v Essien ${ }^{92}$ and Sehindemi v Governor of Lagos State. ${ }^{93}$ In Essien's case, the respondent commenced the action and sought determination of the constitutionality of some of the provisions of a State $\mathrm{Law}^{94}$ which was in conflict with a Federal enactment. ${ }^{95}$ Apparently, this is

Prashad, and Srimandir Nath Jain. Principles of Administrative Law. NM Tripathi, 1979; V. S. Deshpande, "Standing and Justifiability", Journal of Indian Law Institute Vol.13, (1971):153; Burns, Y. and M. Kidd, "Administrative Law \& Implementation of Environmental Law" in. Environmental Management in South Africa, eds. Strydom, Hendrik Andries, and N. D. King, (Juta and Company Ltd, 2009.

88 (1961) 1 N.S.C.C 165.

89 Children and Young Persons Law, 1958 (Northern Region No 28 of 1958).

90 [1981] 2 NCLR 358.

91 Per Sowemimo JSC; Bello JSC; Idigbe JSC; Obaseki JSC; and Nnamani JSC.

92 (2004) 7 NWLR (pt. 872) 288.

93 (2006) 10 NWLR (pt. 987) 1.

94 Akwa Ibom State Independent Electoral Commission Laws, 2000 and 2002.

95 Electoral Act, 2001. 
another public interest suit testing the rationale and constitutionality of a local law. Surprisingly, the Court of Appeal dismissed the suit on the ground that a private individual has no standing to seek declaration with respect to a matter of public importance unless the private right of such individual is infringed. Similarly, Sehindemi's case ended in the same way - denial of right to enforce infringed rights of the public at large. The trend continued until sometimes in 2009 when the new rules was enacted.

\section{FUNDAMENTAL RIGHTS (ENFORCEMENT PROCEDURE) RULES, 2009}

As practising lawyers and judges were criticising the 1979 Rules so also were the victims of human rights abuses whose cases were dismissed on various grounds some of which are highlighted above. In tandem with this clarion call, human rights activists and writers ${ }^{96}$ in Nigeria have expressed concern over the inadequacies apparent in the rules and called for immediate amendment or total repeal of the Rules. The hue and cry of injustice created by the 1979 Rules was made, echoed and heard in many quarters. Responding to these calls, the then Chief Justice of Nigeria (Idriz Legbo Kutigi) enacted new Rules ${ }^{97}$ in exercise of power conferred on him by the Constitution. ${ }^{98}$ The new Rules have simplified the procedure for the enforcement of rights in Nigeria. The compelling question, however, is to what extent have the new Rules ameliorated problems created by the 1979 Rules? Answers to this question are the subject of discussion in this segment.

\section{Innovations in the 2009 Enforcement Rules}

The 2009 Rules has brought many innovations applauded by all and sundry. Although its implementation is still at an embryonic stage, it is expedient to examine some of the innovations that will assist victims of human rights abuse, lawyers and judges when faced with interpretation and application of the rules.

\footnotetext{
$96 \quad$ Femi Falana, Fundamental Rights Enforcement in Nigeria, xvi -xvii.

97 Fundamental Rights (Enforcement Procedure) Rules, 2009; it is made pursuant to Chapter IV of the Constitution. It takes effect from 1st December, 2009. See the Federal Republic of Nigeria Official Gazette No. 74, Vol. 96, Lagos of 17th November 2009. It is herein subsequently referred to and interchangeably used as '2009 Rules' or 'new rules'.

98 Section 46 (3) 1999 Constitution (as amended).
} 


\section{The overriding objectives of the 2009 Rules}

A clear reading and understanding of the preamble to the 2009 Rules would indicate that the overriding objective of the Rules is to water down the rigidity or harshness of the old rules. For example, it is now incumbent on the court to constantly and conscientiously give effect to the overriding objective of the Rules at every stage of a human rights action, especially whenever it is exercising any power given to it by the Rules or any other law and whenever it is applying or interpreting any law. ${ }^{99}$ Parties as well as their legal representatives are enjoined to help the court to further and achieve the overriding objectives of the Rules. This duty includes citing relevant legal authorities and statutes that will assist in the cause of justice even if they are obtainable and applicable in other jurisdictions. ${ }^{100}$ It becomes apparent that any legal practitioner who fails in his duty to do this runs foul of the rules of professional conduct and he is liable to be sanctioned. ${ }^{101}$

The overriding objectives of the Rules are aptly stated in the preamble. The Rules intend to ensure that the Constitution, especially Chapter IV and the African Charter on Human and Peoples' Rights (African Charter) are expansively and purposefully interpreted and applied with a view to advancing and realising the rights and freedom contained in them and affording the protection intended by them. ${ }^{102}$ Not only that, overriding objectives include advancing but not restricting the applicant's rights and freedoms by courts. This is realisable by respecting any municipal, regional and international bill of rights cited to courts or brought to their attention or of which the courts are aware of. This is practicable whether these bills constitute instruments in themselves or form part of larger documents like constitutions. This is a radical development aimed at ensuring easy interpretation, application and enforcement of infringed human rights.

\section{Mode of enforcement of human rights in the 2009 Rules}

One of the major defects which the 2009 Rules has come to cure is the inordinate mode of commencement of human rights proceedings under the old Rules. It would be recalled that in order to enforce an

\footnotetext{
99 Any law here includes the African Charter on Human and People's Right (Ratification and Enforcement) Act Cap. A9, LFN 2004.

100 For example, see the dictum of Adekeye, JCA in Inspector-General of Police $v$ All Nigeria Peoples Party (2008) 12 WRN 65 at 97.

101 See Rule of Professional Misconduct 2007.

102 In order to give effect and meaning to Chapter IV of the Constitution and Africa Charter on Human and Peoples' Right.
} 
infringed right, an applicant must commence the proceeding by adopting procedures laid down by the rules. However, the 2009 Rules bring with it a pragmatic approach. The combined effect of adoption of the African Charter with the Constitution is that human rights can be enforced in any mode convenient to the applicant and the court. With the adoption of the African Charter by the new rules, the Court of Appeal ${ }^{103}$ has had an opportunity to state that the mode prescribed under the Rules is just one of the modes of commencing enforcement of rights.

Now, it is apparent that procedures for commencing enforcement of infringed rights in the Constitution and the African Charter include the judicial review of certiorari, mandamus, prohibition, habeas corpus, and originating application. ${ }^{104}$ Thus, an applicant can adopt any procedure convenient for him in order to enforce his infringed rights. If it pleases an applicant, he may adopt the new mode prescribed by the 2009 Rules in bringing to the court proceedings involving enforcement of his infringed right. This position is reinstated by the court in the following words: "The Fundamental Rights (Enforcement Procedure) Rules enacted pursuant to the Constitution is one of the means by which a person may seek to enforce the rights guaranteed by the African Charter and Chapter IV of the Constitution."105

\section{Enforcement of rights outside the State of breach (Jurisdiction)}

The problem of enforcing infringed rights outside the state of infringement stemmed from the non-availability of the Federal High Court in some states particularly where the subject matter or infringed rights comes within the jurisdiction of the Federal High Court. Thus, when confronted with such problem, applicants in most cases prefer to seek redress in another state where a Federal High Courts exists. The stumbling block, as captured in Tukur v. Gongola State Governor, ${ }^{106}$ is the objection to the jurisdiction of the Federal High Court of another state to entertain the matter. As decided in Tukur's case and many other cases that followed, such Federal High Courts of other states

\footnotetext{
103 See Ohakosin v Commissioner of Police, Imo State (2009) 15 NWLR (pt. 1164) 229.

104 Order II Rule 2 says "An application for the enforcement of the Fundamental Human Rights may be made by any originating process accepted by the court which shall, subject to the provisions of these Rules, lie without leave of court." Italics are mine for the purpose of emphasis.

105 Ohakosin v Commissioner of Police, Imo State (2009) 15 NWLR (pt. 1164) 229 at 240 .

106 Ibid.
} 
lack jurisdiction to entertain the matter because the infringement complained about occurred in a different state.

This jurisdictional difficulty is one of the major areas considered and laid to rest by the 2009 rule. The new rule envisages a situation where a right is infringed in a state where the Federal High Court does not exist. It thus permits an applicant in such a difficult situation to enforce his infringed right in the Federal High Court of another state administratively responsible for the state of infringement. ${ }^{107}$ With this in place, it is no longer an issue that a Federal High Court of another state cannot hear and determine human rights enforcement proceedings whose infringement occurred in a different state so long as the Federal High Court has administrative control in the State where the breach or threat of breach occurred.

\section{Locus standi of the applicant}

An applicant under the regime of the 1979 Rules had to convince the court that he has locus standi to institute the proceedings before his application for enforcement of human rights could be maintained. As earlier discussed, many human rights cases were lost as a result of the inability of applicants to successfully establish their locus. However, the situation is no longer the same under the new rules. With the inception of the new rules, "no human rights cases may be dismissed or struck out for want of locus standi." 108 Thus, any wife, husband, brother, friend or a relative who has personal knowledge concerning an infringement can apply to enforce the rights of the applicant. Not only that, unlike in the past, such wife or husband or relative of the applicant can depose an affidavit on behalf of the applicant stating, among other facts, that the applicant is unable to personally depose such affidavit. ${ }^{109}$ Thus, it can presumably be said that those cases that were dismissed on the basis of no locus standi are no longer correct law.

\section{Time frame within which to commence proceedings}

The old rules prescribed 12 months as the time frame within which enforcement of human rights proceedings must be commenced and failure to commence within this period has led to dismissal of many human rights enforcement cases. ${ }^{110}$ The position of the 2009 Rules

\footnotetext{
107 See proviso to Order II Rule 1 of the 2009 Rules.

108 See Preamble 3 (e) of the 2009 Rules.

109 See Order II Rule 4.

110 See Egbe v Adefarasin (1985) 1 NWLR (pt. 3) 549; Kayode Akanbi v Constable Dauda Gnagnatus (1984) 5 NCLR 722; Abia State University v Anyaibe (1996) 3 NWLR (pt. 439) 646; and Oguegbe v Inspector General of Police (1999) 1 FHCLR 59.
} 
is diametrically different from the old rules. With the new rules, an application to secure the enforcement of fundamental rights cannot become statute barred so as to extinguish the right of an applicant to institute an action in the High Court. ${ }^{111}$ In other words, the right of an applicant to file an action for enforcement of fundamental rights can be exercised at any time, regardless of when the violation occurred or the status of the respondent. Hence, limitation of time which had denied many applicants of the right to enforce their infringed rights is now a thing of the past.

\section{Applicability of Public Interest Litigation}

Public interest litigation has gained ground in countries like Australia, USA, India and some other jurisdictions in Europe. In fact, India is regarded as the home of public interest litigation due to its early pragmatic adoption and reception of public interest litigation. ${ }^{12}$ Development in these jurisdictions influences certain portions of the 2009 Rules. Specifically, the new rules move away from traditional denial of public interest litigation and adopts its concept in totality. For example, the Rules advocate proactive pursuit of enhanced access to justice for all classes of litigants. ${ }^{113}$ The class of litigants in this respect include the poor, the illiterate, the uninformed, the vulnerable, the incarcerated and the unrepresented. ${ }^{114}$ The Rules go further to welcome and encourage public interest litigation in the human rights field and state that "no human rights case may be dismissed or struck out for want of locus standi."

With this innovation, the coast is clear for advocates, human rights activists and non-governmental organisations to institute human rights applications on behalf of any potential applicant who may be handicapped from instituting the same by himself. Proactively, the rules classify an applicant to include anyone acting in his own interest; anyone acting on behalf of another person; anyone acting as a member of, or in the interest of a group or class of persons; anyone acting in the public interest; and an association acting in the interest of its members

\footnotetext{
$111 \quad$ Falana Femi, Fundamental Rights Enforcement in Nigeria, 87.

112 Rahman. K. Salman \& Olabisi. O. Ayankogbe, "Denial Of Access To Justice In Public Interest Litigation In Nigeria: The Need To Learn From The Indian Judiciary," Journal of the Indian Law Institute, Vol. 53, No.4, (2012): 594.

113 The courts are enjoined to ensure that the fundamental rights of the disadvantaged segment of the society are secured and enforced.

114 See para 3(d) of the preamble to the Rules.

115 See para 3 (e) of the preamble to the Rules.
} 
or other individuals or groups. ${ }^{116}$ The new position reiterates the earlier Supreme Court decision in the case of Fawehinmi $v$ The President of Nigeria ${ }^{117}$ Indeed, this is the peak of the new Rules' improvement over the old rules.

\section{CONCLUSION}

Many applicants who had suffered infringement of their fundamental rights from the government, corporations and individuals had set-backs in the process of enforcement of these rights. Such set-backs occurred as a result of procedural irregularities and technicalities inherent in the 1979 Fundamental Rights (Enforcement Procedure) Rules. As a result of this development, many lost interest and hope of enforcing their fundamental rights in the judicial system while other regarded the rules as a weapon meant to protect the tyrannical activities of the government of the day.

In 2009, what appears to be succour in the enforcement of fundamental human rights came. All the seemingly difficult areas that have denied many applicants the enforcement of their rights were addressed. These ranged from the heavy duty placed on courts and legal practitioners to expedite human rights applications, the courts and applicants to avoid technicalities, demystification of the principle of locus standi to the encouragement of public interest litigation and outright removal of limitation action clauses. This is a very positive development. Although, it is early to comment on the effectiveness and desirability of these on the court and applicants, yet it is believed that if properly implemented the court, legal practitioners and victims of human rights abuses will have a cause to smile. For the new Rules to work effectively, the following suggestions are put forward.

Firstly, it is still doubtful whether the 2009 Rules empower the Chief Justice to expand the rights to be enforced to include the African Charter on Human and Peoples' Rights. It is strongly believed that he does not have such powers. The constitution ${ }^{118}$ empowers him to make rules 'with respect to the practice and procedure of a High Court for the purposes of this section.' He is to make rules for enforcement and not to stipulate the right to be enforced. Also this 'section' refers to section 46 of the constitution. Section 46(1) restricts the rights to be enforced to breaches of the provision 'of this chapter'. This "chapter" is chapter

\footnotetext{
$116 \quad$ Ibid.

117 (2008) 23 WRN 65.
}

118 See section 46 (3) of the 1999 Constitution (as amended). 
IV of the Constitution with specific rights. By expanding the rights to include rights provided for by African Charter, he has unconsciously included other rights in the Charter that are not expressly provided for in Chapter IV of the Constitution.

Strictly speaking, this is not the object of section 46(1) of the Constitution and by inference section 46(3) of the Constitution. Where a provision of the Constitution empowers anybody, organ or agency to do anything, it is our humble submission that any act or thing done outside the constitutional limit is unconstitutional, ultra vires, and thus null and void. This is akin to a donee of a power of attorney acting beyond the terms of his authority. Whatever he does outside the power is a nullity. In order to validate the Chief Justice's power in this regard, it is suggested that the limitation in section 46(1) of the Constitution be removed via amendment of the Constitution. Unless this is done, the incongruence of the Chief Justice's power with the constitutional provision will be a ground for challenging breach of rights in the African Charter. Fortunately, the Constitution is undergoing a series of pragmatic reviews and amendments. Thus, this is the period apposite for such amendment; otherwise the inconsistency may make nonsense of the enforcement of rights enshrined in the African Charter.

Secondly, there is need for creation of specialised courts to be known and called 'human rights courts.' Human rights law is a specialised area and as such it should be given the necessary attention it deserves. This is coupled with the nature of human rights abuses in Nigeria which has given the country a negative image. Sometime ago in Nigeria, industrial disputes became so rampant and there were calls for urgent solutions. One of the solutions in place is the creation of an Industrial Court by the Constitution. Today, many industrial disputes which would have congested the available courts are being handled by specialised courts-the Industrial Courts. Since this solution has worked for industrial disputes, perhaps it is time for the creation of human rights courts to handle human rights abuse cases. If regions like Europe, Americas and Africa could establish functional human rights courts, establishing human rights court in a country like Nigeria will be a good pacesetter for other countries. Such court will emulate and adopt the long-existing structures of these courts which will in turn enhance its performance when created.

It is not sufficient to establish human rights courts and amend the law to accommodate all spheres of human rights practice and law. There is also the need to have experienced and efficiently trained personnel to be in charge of implementation, protection and promotion of human rights. In other words, human rights practice has a lot to do with all 
stakeholders in terms of their experience and training. Therefore, it is crucial that there be constant training and re-training of the judicial officers, police, prison officers and all other law enforcement agencies in Nigeria. This set of people are directly involved in implementing, protecting and promoting human rights in Nigeria. Therefore, training and re-training of such personnel will not only enhance their performance in the human rights implementation, protection and promotion, it will also reduce to the barest minimum human rights abuses which normally occurs via their actions or inactions.

Presently, a few cases have been decided by the lower courts based on the new Rules, very few of these cases are at the appeal stage. Thus, it might not be adequate to comment on the practicability and effectiveness of the Rules. However, as the Rules stand, it has apparently come to remedy some of the inherent defects in the old rules. It is hoped that if the aforementioned suggestions are adopted and implemented, the new Rules will have a better chance of success. 
